Mycologia, 98(4), 2006, pp. 571-583.

(C) 2006 by The Mycological Society of America, Lawrence, KS 66044-8897

\title{
The family Pleosporaceae: intergeneric relationships and phylogenetic perspectives based on sequence analyses of partial 28S rDNA
}

Rampai Kodsueb

Department of Biology, Faculty of Science, Chiang Mai University, Chiang Mai, Thailand

Vijaykrishna Dhanasekaran

Centre for Research in Fungal Diversity, Department of Ecology Eु Biodiversity, The University of Hong Kong, Pokfulam Road, Hong Kong

André Aptroot

Centraalbureau voor Schimmelcultures, P.O. Box 85167, 3508 AD Utrecht, The Netherlands

Saisamorn Lumyong

Department of Biology, Faculty of Science, Chiang Mai University, Chiang Mai, Thailand

Eric H.C. McKenzie

Landcare Research, Private Bag 92170, Auckland, New Zealand

Kevin D. Hyde

Rajesh Jeewon $^{1}$

Centre for Research in Fungal Diversity, Department of Ecology $\mathcal{E}$ Biodiversity, The University of Hong Kong, Pokfulam Road, Hong Kong

Abstract: The Pleosporaceae is an important loculoascomycete family. There has been disagreement, however, regarding the taxonomic placement of many genera within this family. This study investigates phylogenetic relationships among the genera Cochliobolus, Kirschsteiniothelia, Leptosphaerulina, Macroventuria, Pleospora, Pyrenophora, and Wettsteinina. Partial 28S rDNA sequences from taxa within these genera were analyzed with maximum parsimony, likelihood and Bayesian methods. Cochliobolus can be segregated broadly into two groups as previously proposed. Pleospora is polyphyletic in its current sense. Taxa with Stemphylium anamorphs are closely related to Cochliobolus and fit within the Pleosporaceae, whereas the affinities of Pleospora herbarum and P. ambigua are still ambiguous. Pyrenophora constitutes a monophyletic group within the Pleosporaceae, whereas Leptosphaerulina and Macroventuria appear to share phylogenetic affinities with the Leptosphaeriaceae and Phaeosphaeriaceae. Phylogenies indicate that Wettsteinina should be excluded from the Pleosporaceae. Similar findings are reported for Kirschstei-

Accepted for publication 30 May 2006.

${ }^{1}$ Corresponding author. E-mail: rrjeewon@hku.hk, rjeewon@ graduate.hku.hk niothelia, which is probably polyphyletic. Anamorphic characters appear to be significant (especially in Cochliobolus) while ascospore morphologies, such as shape and color and substrate occurrence are poor indicators of phylogenetic relationships among these loculoascomycetes.

Key words: anamorphs, ascospore morphology, Loculoascomycetes, phylogeny, Pleospora, polyphyletic, ribosomal DNA

\section{INTRODUCTION}

The largest family within the Pleosporales, Pleosporaceae, comprises 17 genera and 111 species (Kirk et al 2001). Species are parasites or saprobes on wood and dead herbaceous stems or leaves (Sivanesan 1984). The classification in the Pleosporaceae has been based primarily on the Pleospora type of centrum development (Dong et al 1998) and asci that are interspersed with pseudoparaphyses in the ascostroma. These pseudoparaphyses originate above the hymenial layer and grow downward among the asci to fuse at the base of the locule (Wehmeyer 1975). Ascomata are perithecial, initially immersed and become erumpent and are usually black and sometimes hairy or setose. Asci are fissitunicate, cylindrical, with an ocular chamber and pseudoparaphyses are cellular. Ascospores are usually brown and phragmosporous or dictyosporous (Dong et al 1998, Kirk et al 2001). Many pleosporaceous taxa are important plant pathogens. For instance Cochliobolus heterostrophus causes southern corn leaf blight and Pyrenophora graminea is the causal agent of barley leaf stripe (Agrios 2005). Their anamorphs are usually hyphomycetes and also have been reported to cause plant disease in cereals (e.g. Bipolaris maydis, Exserohilum turcicum and Helminthosporium oryzae) (Farr et al 1989, Berbee 1996, Krupinsky et al 2004, Agrios 2005).

The Pleosporaceae historically was placed in the Sphaeriales (e.g. Winter 1887, Ellis and Everhart 1892, Lindau 1897) based on immersed perithecia containing paraphyses (Wehmeyer 1975). The family then was transferred to the Pseudosphaeriaceae, which was later raised to ordinal rank as the Pseudosphaeriales (Theissen and Sydow 1917, Wehmeyer 1975). Luttrell (1955) treated the name Pseudosphaeriales as a synonym of the Dothideales and suggested that pseudoparaphyses were important in 
their taxonomy. He considered the Pseudosphaeriales as synonym of the Pleosporales and assigned the Pleosporaceae, Venturiaceae and Lophiostomataceae, to the Pleosporales. Such a scheme largely was accepted by other mycologists (e.g. Wehmeyer 1975). Wehmeyer (1975) pointed out that the family Pleosporaceae has never been clearly delimited following Luttrell's concept and as a result taxa with ascostromata of many different types, which previously were placed in other families, were placed arbitrarily in the Pleosporaceae.

The family Pleosporaceae is a heterogeneous group of bitunicate ascomycetes with genera primarily included based on ascospore characteristics, including shape, color, septation, pigmentation and presence or absence of mucilaginous sheaths (Luttrell 1955, 1973; Wehmeyer 1961, 1975; Eriksson 1981; Sivanesan 1984; Barr 1987b; Abler 2003). Other families, such as the Leptosphaeriaceae, Melanommataceae, Phaeosphaeriaceae and Sporormiaceae, however, also possess morphological characters similar to those of the Pleosporaceae, and this has resulted in considerable ambiguity and confusion in intergeneric and familial classification (Luttrell 1955, 1973; Wehmeyer 1961, 1975; von Arx and Müller 1975; Sivanesan 1984; Barr 1987a, b; Eriksson and Hawksworth 1986, 1991). Most genera in these families have morphological characters that overlap in many respects and the taxonomic organization among them has been modified on several occasions (TABLE I). Barr (1987b) redefined the Pleosporaceae to include Clathrospora (=Comoclathris), Kirschsteiniothelia, Lewia and Pleospora and grouped Cochliobolus, Pyrenophora and Setosphaeria into the family Pyrenophoraceae. Berbee (1996) disagreed, suggesting that all those genera belong to the Pleosporaceae.

Given the considerable taxonomic confusion, this study, based on phylogenetic analyses of rDNA sequence data, was undertaken to (i) verify the familial placement of these genera and assess whether they represent natural groups, (ii) determine which morphological characters are phylogenetically significant and therefore are useful for generic delineation and (iii) assess whether phylogenies based on molecular characters are concordant with any of the traditional morphology-based classification schemes.

\section{MATERIALS AND METHODS}

DNA extraction. - Twenty isolates of Pleosporaceae ( $\mathrm{Co}$ chliobolus [two species], Kirschsteiniothelia [one species], Leptosphaerulina [four species], Macroventuria [two species], Pleospora [four species], Pyrenophora [four species] and Wettsteinina [three species]) and six species of allied genera (Karstenula rhodostoma, Leptosphaeria maculans,
Lophiostoma caulium, Massarina ramunculicola, Phaeosphaeria vegans and Venturia carpophila) were selected for this study. Species names and accession numbers of the isolates in this study are listed (TABLE II). For each isolate, pure cultures were plated on potato dextrose agar and incubated at $25 \mathrm{C}$ 10-20 d before DNA extraction. Genomic DNA was extracted from fresh fungal mycelia following a protocol as outlined by Jeewon et al (2002, 2003, 2004) and Cai et al (2005). Briefly, mycelia were scraped off from the surface of the plate. The mycelia were ground with $200 \mathrm{mg}$ of sterilized quartz sand and $600 \mu \mathrm{L}$ of $2 \times$ CTAB extraction buffer (2\% w/v CTAB, $100 \mathrm{mM}$ Tris-HCL, $1.4 \mathrm{M} \mathrm{NaCl}, 20 \mathrm{mM}$ EDTA, $\mathrm{pH}$ 8) in a $1.5 \mathrm{~mL}$ Eppendorf tube. The contents were incubated at $60 \mathrm{C}$ in a water bath $40 \mathrm{~min}$ with gentle swirling every $10 \mathrm{~min}$. The solution was extracted three times with an equal volume of phenol:chloroform (1:1) at $13000 \mathrm{~g} 30 \mathrm{~min}$ until no interface was visible. The upper aqueous phase containing the DNA was precipitated by addition of 2.5 volumes of absolute ethanol and kept at $-20 \mathrm{C}$ overnight. The precipitated DNA was washed two times with $70 \%$ ethanol, dried under vacuum and suspended in TE buffer ( $1 \mathrm{mM}$ EDTA, $10 \mathrm{mM}$ Tris-HCl, $\mathrm{pH} 8.0$ ) and treated with RNase $(1 \mathrm{mg} / \mathrm{mL})$ before DNA amplification.

DNA amplification and sequencing of $28 S$ rDNA.-Approximately 900 nucleotides at the $5^{\prime}$ end of the 28S rDNA region were amplified by primer pairs LROR/LRO5 (Vilgalys and Hester 1990). PCR was carried out in $50 \mu \mathrm{L}$ reaction volume containing $31.7 \mu \mathrm{L}$ sterile water, $5 \mu \mathrm{L}$ of $10 \times \mathrm{Mg}$ free PCR buffer, $3 \mu \mathrm{L}$ of $25 \mathrm{mM} \mathrm{MgCl}_{2}$, $4 \mu \mathrm{L}$ of $2.5 \mathrm{mM}$ deoxyribonucleotide triphosphate (dNTPs), $1.5 \mu \mathrm{L}$ of each $10 \mu \mathrm{M}$ primers (LROR and LRO5), $3 \mu \mathrm{L}$ of DNA template, $0.3 \mu \mathrm{L}$ of 2.5 units of Taq DNA polymerase (Promega, Madison, Wisconsin). Typical amplification parameters were: initial denaturation of $95 \mathrm{C}$ for $3 \mathrm{~min}$; 35 cycles of denaturation at $95 \mathrm{C} 1 \mathrm{~min}$, annealing at $52 \mathrm{C} 50 \mathrm{~s}$ and extension at 72 C $1 \mathrm{~min}$ and final extension of $72 \mathrm{C} 10 \mathrm{~min}$. Doublestranded DNA products were purified with GFX $^{\mathrm{TM}}$ PCR DNA and Gel Band Purification Kit (Amersham Biosciences, catalogue No. 27-9602-01) following manufacturer's protocol. Sequencing reactions were performed and sequences determined automatically in an Applied Biosystem 3730 Genetic Analyzer/Sequencer (Genome Research Center, The University of Hong Kong) using PCR primers mentioned above.

Phylogenetic analyses.-Fifty-four taxa from different fungal families were aligned initially with the computer program Bioedit (Hall 1999) and Clustal X (Thompson et al 1997) with default parameter settings, and alignments were manually edited by inserting gaps for optimization using Se-Al (Rambaut 1996). Phylogenetic analyses of LSU rDNA were performed with maximum parsimony employing a heuristic search (1000 random replicates) in PAUP* v 4.0b10 (Swofford 2002). Ambiguously aligned regions also were excluded from the phylogenetic analyses. 


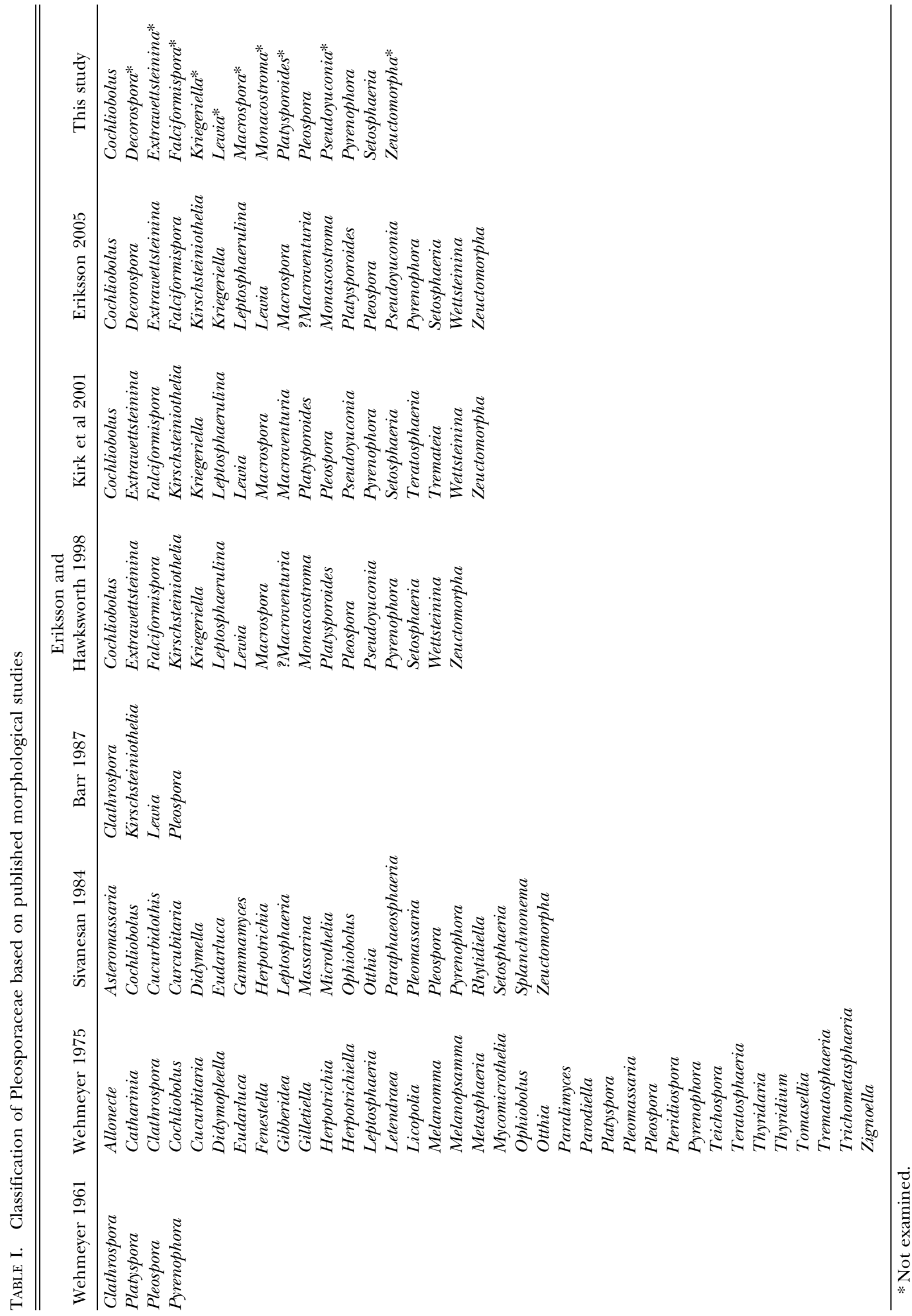


TABLE II. Fungal species and GenBank accession number for taxa used in phylogenetic analyses

\begin{tabular}{|c|c|c|c|}
\hline Species & Isolates/sources & $\begin{array}{c}\text { GenBank Accession } \\
\text { number }\end{array}$ & Family* \\
\hline \multicolumn{4}{|l|}{ Ingroup } \\
\hline Bimuria novae-zelandiae & CBS107.79 & AY016356 & Melanommataceae \\
\hline Bipolaris papendorfii & $9084 \mathrm{c}$ & AF163980 & Anamorphic Cochliobolus, Pleosporaceae \\
\hline Cochliobolus cynodontis & BRIP16821 & AF163982 & Pleosporaceae \\
\hline Cochliobolus hawaiiensis & BRIP15933 & AF163979 & Pleosporaceae \\
\hline Cochliobolus heterostrophus & CBS134.39 & AY544645 & Pleosporaceae \\
\hline Cochliobolus lunatus & $95 / 1937 b$ & AF163988 & Pleosporaceae \\
\hline Cochliobolus nodulosus & ICMP10306 & AY849940 & Pleosporaceae \\
\hline Cochliobolus pallescens & ICMP11023 & AY849941 & Pleosporaceae \\
\hline Curvularia oryzae & MRL1089 & AF163991 & Anamorphic Cochliobolus, Pleosporaceae \\
\hline Curvularia brachyspora & ATCC58872 & AF279380 & Anamorphic Cochliobolus, Pleosporaceae \\
\hline Curvularia heteropogonicola & IMI268958 & AF163986 & Anamorphic Cochliobolus, Pleosporaceae \\
\hline Dothidea ribesia & CBS195.58 & AY016360 & Dothideaceae \\
\hline Dothidea sambuci & CBS198.58 & AF382387 & Dothideaceae \\
\hline Karstenula rhodostoma & CBS690.94 & AY787933 & Melanommataceae \\
\hline Kirschsteiniothelia elaterascus & HKUCC7769 & AY787934 & Pleosporaceae \\
\hline Leptosphaeria doliolum & ATCC32813 & $\mathrm{U} 43473$ & Leptosphaeriaceae \\
\hline Leptosphaeria maculans & ICMP13554 & AY849946 & Leptosphaeriaceae \\
\hline Leptosphaerulina argentinensis & CBS569.94 & AY849947 & Pleosporaceae \\
\hline Leptosphaerulina australis & ICMP10312 & AY849948 & Pleosporaceae \\
\hline Leptosphaerulina briosiana & CBS441.74 & AY849949 & Pleosporaceae \\
\hline Leptosphaerulina trifolii & CBS235.58 & AY849950 & Pleosporaceae \\
\hline Letendraea helminthicola & CBS884.85 & AY016362 & Tubeufiaceae \\
\hline Lophiostoma caulium & CBS 623.86 & DQ528763 & Lophiostomataceae \\
\hline Macroventuria anomochaeta & CBS525.71 & AY787936 & Pleosporaceae \\
\hline Macroventuria wentii & CBS526.71 & AY849952 & Pleosporaceae \\
\hline Massarina ramunculicola & HKUCC7649 & DQ528762 & Lophiostomataceae \\
\hline Microxyphium citri & CBS451.66 & AY004337 & Anamorphic Ascomycetes \\
\hline Myriangium duriaei & CBS260.36 & AY016365 & Myriangiaceae \\
\hline Phaeosphaeria avenaria & AFTOL-ID280 & AY544684 & Phaeosphaeriaceae \\
\hline Phaeosphaeria vagans & CBS604.86 & AY849953 & Phaeosphaeriaceae \\
\hline Pleomassaria siparia & CBS279.74 & AY004341 & Pleomassariaceae \\
\hline Pleospora ambigua & CBS366.52 & AY787937 & Pleosporaceae \\
\hline Pleospora halophila & CBS410.73 & AY849955 & Pleosporaceae \\
\hline Pleospora herbarum var. herbarum & CBS191.86 & AF382386 & Pleosporaceae \\
\hline Pleospora sedicola & CBS109843 & AY849958 & Pleosporaceae \\
\hline Pleospora tomatonis & CBS109844 & AY849959 & Pleosporaceae \\
\hline Preussia terricola & AFTOL-ID282 & AY544686 & Sporormiaceae \\
\hline Pyrenophora dictyoides & ICMP14523 & AY849960 & Pleosporaceae \\
\hline Pyrenophora seminiperda & ICMP6169 & AY849961 & Pleosporaceae \\
\hline Pyrenophora tetrarhenae & ICMP6139 & AY849962 & Pleosporaceae \\
\hline Pyrenophora trichostoma & CBS392.54 & AY849963 & Pleosporaceae \\
\hline Pyrenophora triticirepentis & AFTOL-ID173 & AY544672 & Pleosporaceae \\
\hline Setomelanomma holmii & CBS110217 & AF525678 & Dothideales Incertae sedis \\
\hline Setosphaeria monoceras & CBS154.26 & AY016368 & Pleosporaceae \\
\hline Stylodothis puccinioides & CBS193.58 & AY004342 & Dothideaceae \\
\hline Trematosphaeria heterospora & CBS644.86 & AY016369 & Melanommataceae \\
\hline Venturia carpophila & ICMP5402 & AY849967 & Venturiaceae \\
\hline Venturia hanliniana & ATCC96019 & AF050290 & Venturiaceae \\
\hline Westerdykella cylindrica & CBS454.72 & AY004343 & Sporormiaceae \\
\hline Wettsteinina dryadis & CBS448.54 & AY849968 & Pleosporaceae \\
\hline Wettsteinina macrotheca & CBS647.86 & AY849969 & Pleosporaceae \\
\hline Wettsteinina pachyasca & CBS646.86 & AY849970 & Pleosporaceae \\
\hline \multicolumn{4}{|l|}{ Outgroup } \\
\hline Glyphium elatum & CBS268.34 & AF346420 & Mytilinidiaceae \\
\hline
\end{tabular}

* Familial classification follows Kirk et al (2001). 
Maximum parsimony analyses were carried out treating gaps as missing and as fifth character (newstate) with the exclusion of ambiguously aligned portions. Parsimony analyses also were carried out including the ambiguously aligned portions as recoded characters using INAASE (Lutzoni et al 2000), while the gaps were treated as fifth character. Heuristic search option with the tree-bisectionreconnection (TBR) branch swapping, MULTREEs options (saving all optimal trees) effective and random sequence additions set to 1000 was employed to generate parsimony trees. Reliability for each branch of the best tree was assessed by the bootstrap method (Felsenstein 1985) with 1000 replicates (one random addition of sequences per bootstrap replicate). The model of substitution used for Bayesian and ML was chosen with Mrmodeltest 2.2 (Nylander 2004). Independent Bayesian phylogenetic analysis was performed in MrBayes 3.0 (Huelsenbeck and Ronquist 2001) using a uniform SYM $+\mathrm{I}+\mathrm{G}$ model, as selected by hLRT in Mrmodeltest 2.2([SYM+I+G] lset nst $=6$ rates $=$ invgamma; prset statefreqpr $=$ fixed $($ equal $))$. The Metropolis-coupled Markov chain Monte Carlo (MCMC) sampling approach was used to calculate posterior probabilities. Four simultaneous Markov chains, three heated and one cold, were run under a general time reversible (GTR) model of sequence evolution and gamma approximation for rate variation among sites. Chains were analyzed with random starting trees for $10^{6}$ generations. Trees collected before the stable likelihood value point were discarded as "burn-in", (Huelsenback and Ronquist 2001). The remaining trees were used to build a majority rule consensus tree where the percentage of the remained best trees supporting a branch represents the Bayesian posterior probabilities. For maximum likelihood (ML) analyses, tree was inferred with PAUP* using the heuristic search option starting with a parsimony tree with random sequence addition. The Kishino-Hasegawa and Templeton tests were performed to determine whether the trees inferred under different optimality criteria were significantly different.

\section{RESULTS}

The dataset consisted of 54 taxa, each with 886 aligned nucleotide characters, of which 204 (23\%) were parsimony informative. Designated outgroup was Glyphium elatum. A total of 60 characters, which were ambiguously aligned, were excluded in the analyses. This data matrix has been deposited in TreeBase. A heuristic search with random addition of taxa (1000 replicates) and treating gaps as missing and as fifth character (newstate) generated 18 and 60 equally parsimonious trees respectively. All trees were similar in topology and not significantly different. Recoding ambiguously aligned characters (60 in total) in INAASE as four characters and treating gaps as missing data yielded four most parsimonious trees (not statistically different), one of which is shown (FIG. 1). A similar approach to gap treatment was undertaken when dataset was subjected to ML and
Bayesian analyses. Maximum likelihood analyses (under the SYM+I+G evolutionary model as estimated by MrModeltest 2.2) yielded a single tree of log likelihood -5160.83120 . Estimated nucleotide frequencies were: $\mathrm{A}=0.25707, \mathrm{C}=0.20575, \mathrm{G}=0.30922$ and $\mathrm{T}$ $=0.22796$, shape parameter (alpha) was 0.6066 (total length $=714, \mathrm{CI}=0.520, \mathrm{RI}=0.738, \mathrm{RC}=0.383, \mathrm{HI}$ $=0.480)$. Phylogenies obtained from ML analyses were essentially similar to those obtained from MP analyses (results not shown). Bayesian analyses resulted in a tree (total length $=717, \mathrm{CI}=0.517, \mathrm{RI}=$ $0.736, \mathrm{RC}=0.381, \mathrm{HI}=0.483$ ) with identical topologies obtained from other optimality criterion, however support as measured by Bayesian posterior probabilities option was higher and provided significant $(>95 \%)$ support for most of the clades as defined below (FIG. 2). Given that the relationships among ingroups were identical in all analyses, we selected the MP tree (FIG. 1, with bootstrap support based on 1000 replicates) to explain systematic relationships pertaining to members of the Pleosporaceae.

The maximum parsimony tree generated based on sequence analysis of the 28S rDNA dataset produced nine monophyletic clades (FIG. 1). Clades $\mathrm{A}_{1}$ and $\mathrm{A}_{2}$ are members of the Pleosporaceae and did not receive bootstrap support (FIG. 1) but moderate Bayesian support (FIG. 2). Clade $A_{1}$ comprises 16 species from different pleosporaceous genera while Clade $\mathrm{A}_{2}$, characterized only by Pyrenophora species is monophyletic and supported by high Bayesian support $(93 \%)$. Four species of Leptosphaerulina and two species of Macroventuria clustered together within Clade B and form a well supported monophyletic group with $99 \%$ bootstrap support (100\% Bayesian support, FIG. 2). However the position of this clade is not consistent. Phylogenies from Bayesian analyses place this monophyletic group basal to other members of the Phaeosphaeriaceae and Leptosphaeriaceae (Clade $\mathrm{C}$ ), whereas MP analyses place it basal to Clade A (Pleosporaceae). Similar results were obtained from members of the Phaeosphaeriaceae and Leptosphaeriaceae (Clade C) which are basal to Clade B (MP analyses) or basal to Clade A (Bayesian analyses). The latter grouping was moderately supported whereas the node supporting clades B and $\mathrm{C}$ did not receive bootstrap support (FIG. 1). Clade D, characterized by Kirschsteiniothelia elaterascus (Pleosporaceae) and Massarina ramunculicola (Massarinaceae), is monophyletic and strongly supported in all analyses. Clade E, with $97 \%$ bootstrap support, includes Bimuria novae-zealandiae and Karstenula rhodostoma (Melanommataceae) and Letendraea helminthicola (Tubeufiaceae). Preussia terricola and Westerdykella cylindrica clustered together in Clade F (Sporomiaceae). Clade G, another strongly supported 


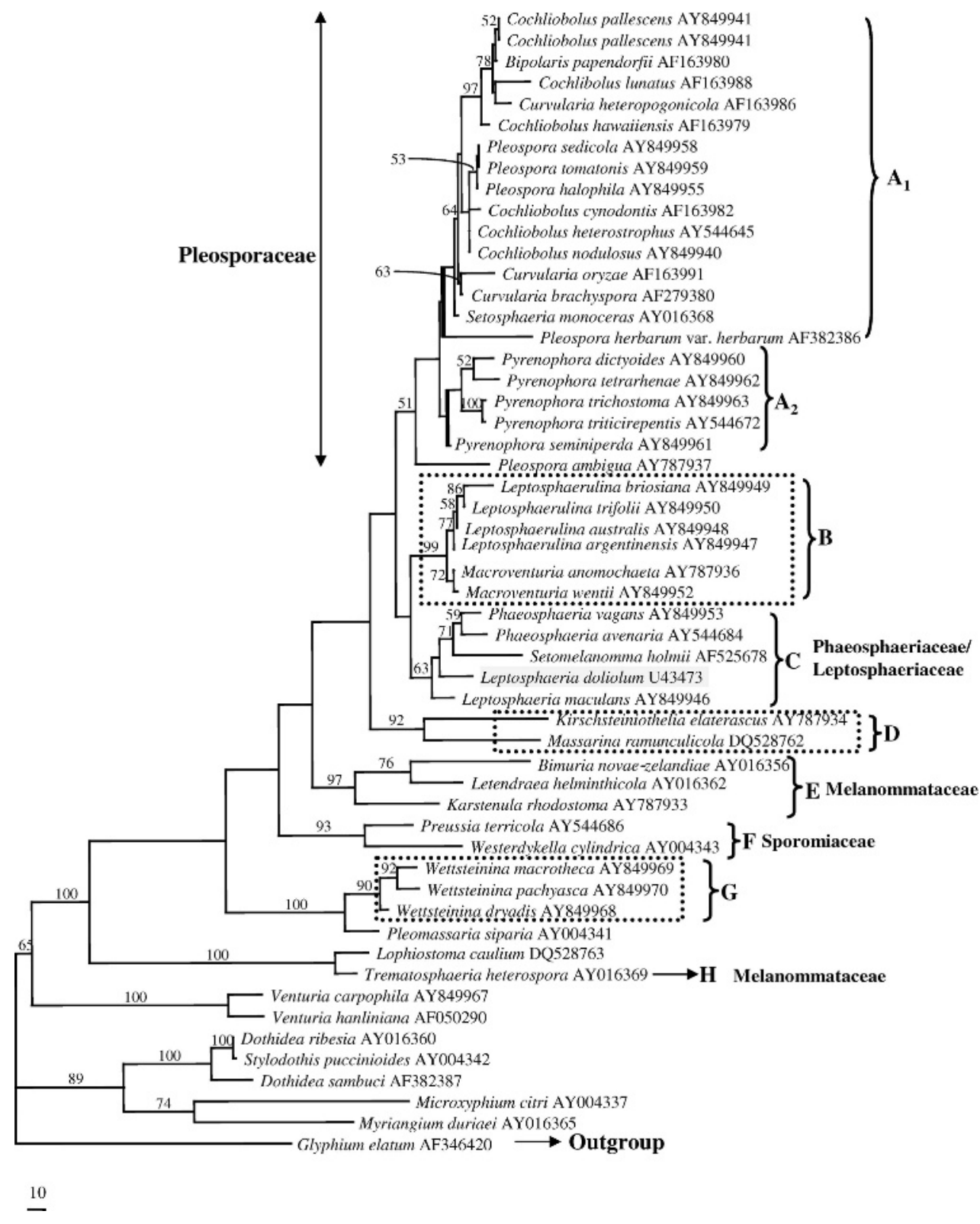

FIG. 1. The maximum parsimony tree generated based on sequence analysis of the 28S rDNA dataset (Total length $=884$, $\mathrm{CI}=0.581, \mathrm{RI}=0.742, \mathrm{RC}=0.432, \mathrm{HI}=0.419)$. Designated outgroup is Glyphium elatum. Bootstrap support values above $50 \%$ shown at nodes are based on 1000 replicates. Clades A-H represent members from different genera forming distinct monophyletic groups.

monophyletic group, consists of three species of Wettsteinina (Pleosporaceae) and basal to them is Pleomassaria siparia (Pleomassariaceae). Lophiostoma caulium (Lophiostomataceae) and Trematosphaeria heterospora (Melanommataceae) nest together in Clade $\mathrm{H}$ with a $100 \%$ bootstrap and Bayesian support.

\section{DISCUSSION}

The family Pleosporaceae (Nitschke 1869) is the largest within the Pleosporales. The taxonomy of this family traditionally has been based on few characters. Various classification schemes have been proposed to arrange taxa in this family, but to date there is considerable taxonomic confusion. This is the first phylogenetic study encompassing a broader taxon sampling from members of the Pleosporaceae. Results obtained generally are congruent with previously described phylogenies and morphology-based classification schemes. Based on current data the monophyly of Pleosporaceae is supported. However there are discrepancies in the taxonomy of several 


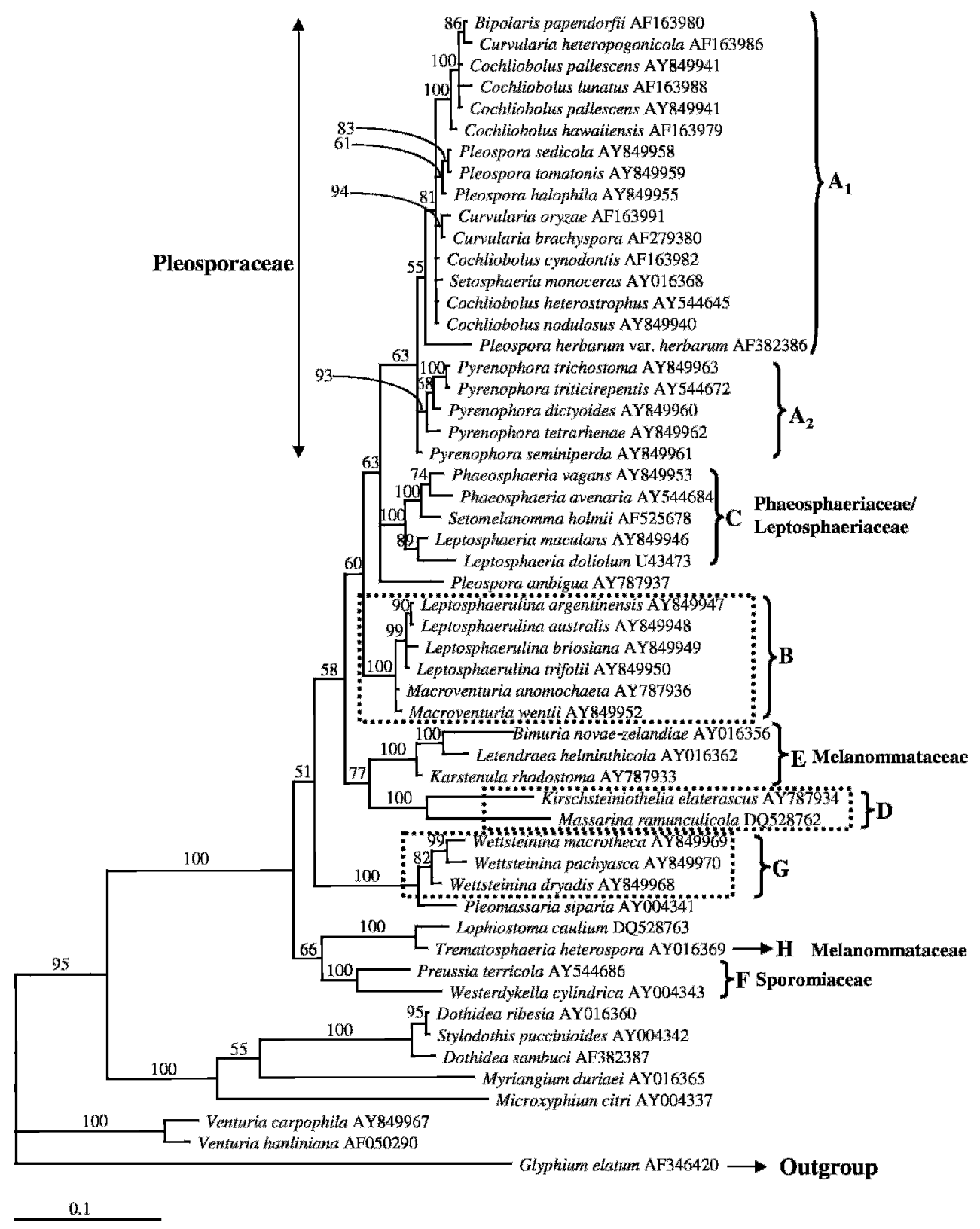

FIG. 2. Phylogeny of the Pleosporaceae and allied genera within Pleosporales estimated under Bayesian analysis (Total length $=717, \mathrm{CI}=0.517, \mathrm{RI}=0.736, \mathrm{RC}=0.381, \mathrm{HI}=0.483)$. Outgroup is Glyphium elatum. Bayesian support is shown above the branches.

pleosporaceous genera, and based on results obtained from rDNA phylogenies and existing morphological data we provide evidence for some reclassification.

Phylogenetics of Cochliobolus, Pleospora and Setosphaeria (Clade $A_{1}$ ).- Several phylogenetic studies within the loculoascomycetes have included Pleospora as a typical representative of the Pleosporales, which is defined by the presence of cellular pseudoparaphyses (Berbee 1996, Dong et al 1998, Silva-Hanlin and Hanlin 1999, Lumbsch
2000, Lumbsch and Lindemuth 2001, Lumbsch et al 2001). Cochliobolus, Pleospora and Setosphaeria currently are accepted genera within the family Pleosporaceae (Sivanesan 1984, Eriksson and Hawksworth 1998, Kirk et al 2001, Eriksson 2005). Our results confirm that these genera are closely related and should be classified in one family, the Pleosporaceae. Cochliobolus has Bipolaris and Curvularia anamorphs, and results obtained from 28S rDNA analyses confirm a close phylogenetic connection between these asexual and sexual fungi. Phylogenies also corroborate find- 
ings reported by Berbee et al (1999) that Cochliobolus species can be divided broadly into two groups. With the inclusion of different taxa in this study we found that C. pallescens (=Curvularia pallescens), Bipolaris papendorfii, C. lunatus (=Curvularia lunatus), C. hawaiiensis (=Bipolaris hawaiiensis) and Curvularia heteropogonicola represent a distinct monophyletic group (similar to Group 2 as defined by Berbee et al 1999). Although morphologically related Cochliobolus species do not constitute a monophyletic lineage. Cochliobolus cynodontis, C. heterostrophus and C. nodulosus form a sister group with three Pleospora species, which are known to produce Stemphylium anamorphs. Berbee et al (1999) also reported that Curvularia heteropogonicola is phylogenetically distinct from Cochliobolus cynodontis, C. heterostrophus and C. nodulosus. Two anamorphic species, Curvularia oryzae and $C$. brachyspora, however do not appear to belong to any of the two groups as defined by Berbee et al (1999). A similar phylogenetic phenomenon was reported for Cochliobolus homomorphus (Berbee et al 1999).

Polyphyly of Pleospora (Clade $A_{1}$ ). - The sister group relationship of Pleospora herbarum and $P$. ambigua is consistent in all analyses. Although morphologically uniform Pleospora does not appear to be monophyletic. Inclusion of $P$. bjoerlingii, $P$. iqbalii and P. rubicunda in our analyses showed that these species are unrelated even to any members of the Pleosporaceae (results not shown). They were found to be basal to Westerdykella cylindrica and Preussia terricola, which are members of the Sporormiaceae. Molecular data from other studies also have shown that Pleospora is a polyphyletic genus (Berbee et al 1996). All pleosporaceous taxa sampled in this study (Clade A) are characterized by septate pseudoparaphyses. There are morphologies, however, that are unique to each genus. Pleospora is distinct from Cochliobolus in having yellow-brown to dark brown ellipsoidal and dictyoseptate ascospores, whereas Cochliobolus has hyaline, filiform, multiseptate ascospores (Sivanesan 1984). An affinity between Curvularia and Setosphaeria can be explained by the fact that both have hyaline ascospores and a Drechslera anamorph (Sivanesan 1984). Their anamorphs also play an important role as plant pathogens in monocotyledonous plants (i.e. Bipolaris hawaiiensis, B. maydis, Curvularia oryzae, Drechslera prolata and Exserohilum turcicum) (Farr et al 1989, Luna et al 2002, Krupinsky et al 2004).

Our results are consistent with published concepts in that anamorphic characters might be useful in the systematics of Cochliobolus, but whether this holds true for Pleospora remains uncertain. For instance Pleospora herbarum is known to possess Stemphylium anamorphs, yet it is not closely related to Pleospora sedicola, $P$. tomatonis and P. halophila, which possess similar Stemphylium anamorphs. Pleospora ambigua (of which no anamorph is known) clusters in the Pleosporaceae but not with other Pleospora species. It should be mentioned that some species of Pleospora also are known to possess Phoma, Dendryphion and Diplodia-like anamorphs (Sivanesan, 1984).

Systematics of Pyrenophora (Clade $A_{2}$ ). - This genus originally was placed in Pleosporaceae by Wehmeyer (1961) but later transferred to a new family, Pyrenophoraceae (Barr 1987b). Later it was included again in the Pleosporaceae (Eriksson 1984, Berbee 1996). Pyrenophora species are morphologically characterized by the absence of definite pseudoparaphyses, which are present in other pleosporaceous taxa. Our results indicate that Pyrenophora is monophyletic and phylogenetically distinct from other members of the Pleosporaceae but cluster within this family.

Sequence analyses also elucidate taxonomic relationships at the species level. Pyrenophora trichostoma and $P$. tritici-repentis cluster with high bootstrap support. Based on morphological similarity these two species have recently been synonymized (Ciuffetti and Tuori 1999). Molecular evidence provided here suggests that they are phylogenetically related but their sequences differ in several base pairs. Whether they should be treated as synonyms cannot be judged with this dataset alone.

Similar results were obtained with $P$. dictyoides and $P$. tetrarhenae (albeit with low support), while $P$. seminiperda appears to be distinct from these other four species. Pyrenophora dictyoides and P. tetrarhenae are characterized by sclerotia that form in culture and ascospores with one or two longitudinal septa in the median cell (Paul and Parbery 1968, Sivanesan 1984). Pyrenophora trichostoma and P. tritici-repentis possess ascospores with mucilaginous sheaths (Dennis 1978, Sivanesan, 1984). Pyrenophora seminiperda is unique in having multitransversely septate with two vertical septa laid at right angles and ascospores thar are surrounded by a mucilaginous sheath when young (Sivanesan 1984). Although taxon sampling is sparse it can be argued that formation of sclerotia, shape of ascospores, septation and gelatinous sheath appear to be significant in delineating species. Based on phylogenetic analysis of ITS and the gpd data Zhang and Berbee (2001) showed that Pyrenophora is monophyletic. They also discussed relationships between most Pyrenophora and anamorphic Drechslera species 
and found that phylogenies were consistent with the relationships proposed from prior morphological studies.

Phylogeny of Leptosphaerulina and Macroventuria (Clade B).- The genera Leptosphaerulina and Macroventuria currently are accommodated in the Pleosporaceae (Eriksson and Hawksworth 1998, Kirk et al 2001, Eriksson 2005). Our molecular analyses show that Leptosphaerulina and Macroventuria are phylogenetically related. This relationship respectively receives moderate bootstrap and high Bayesian support. However a classification within the Pleosporaceae is contentious from the standpoint of phenotypic characters and sequence data. Both genera consist of species that do not possess pseudoparaphyses. This character has been shown to be phylogenetically significant in segregating the bitunicate fungi into two major orders: Dothideales and Pleosporales (Luttrell 1973, Barr 1979, Silva-Hanlin and Hanlin 1999, Lumbsch and Lindemuth 2001). Assuming that this character is taxonomically important as has been postulated by various mycologists (Liu et al 1999, Silva-Hanlin and Hanlin 1999, Liew et al 2000) these two genera would have to be transferred into a different family whose allies include species characterized by the absence of pseudoparaphyses. Silva-Hanlin and Hanlin (1999) also found that although Leptosphaerulina belongs to the Pleosporales, but its affinities to other members of the Pleosporaceae are still unclear.

ITS AND EF- $1 \alpha$ phylogenies revealed that Leptosphaerulina briosiana is closely related to L. trifolii, while $L$. argentinensis is related to $L$. australis (Abler 2003). At the species level, 28S rDNA phylogenies here corroborate with those of Abler (2003). Leptosphaerulina argentinensis and $L$. australis possess 5septate ascospores and differ from $L$. briosiana and $L$. trifolii that have 3-4-septate ascospores. Irwin and Davis (1985) delineated Leptosphaerulina based on ascospore shape and size but most importantly on the number of transverse septa. The phylogenetic segregation of Leptosphaerulina species sampled in this study into two groups corresponds to the number of septa. Borm et al (2002) also have shown that Leptosphaerulina chartatum is related to Pleospora rudis and Pseudotrichia aurata based on 18S rDNA sequence analysis. Silva-Hanlin and Hanlin (1999) also found that $L$. chartatum and L. crassiasca were related to other pleosporaceous taxa, although the presence of pseudoparaphyses does not appear to be common in this genus. Morphologically Leptosphaerulina can sometimes be mistaken for Pleospora because the ascospores often become brown after discharge. Pleospora, however, differs in having larger ascomata and ascospores that turn brown before discharge (Wu and Hanlin 1992). Based on 18S rDNA phylogenies, Silva-Hanlin and Hanlin (1999) found that Leptosphaerulina, although characterized by the absence of pseudoparaphyes, is related to Didymella bryoniae and Didymella ('Mycosphaerella') citrullina (both referred to the Dothideomycetes incertae sedis) and Phaeosphaeria microscopica (Leptosphaeriaceae). It also has been found that Botryosphaeria ribis and B. dothidea (placed in the Dothideales by Sivanesan 1984), which possess pseudoparaphyes, are phylogenetically distinct from other Pleosporales members (Silva-Hanlin and Hanlin 1999). It is highly plausible that the presence of pseudoparaphyes is not a definite characteristic of the Pleosporales as previously argued.

Similar disagreements are reported for the classification of Macroventuria. There are only two species (M. wentii and M. anomochaeta) and they initially were classified in the Venturiaceae (van der Aa 1971), mainly based on perithecia with well developed setae and ascospore shape. This genus has been referred to the Pseudosphaeriaceae by Barr (1982) and recently to the Pleosporaceae (Eriksson and Hawksworth 1998). Macroventuria is similar ecologically and morphologically to other members of the Pleosporaceae. The saprobic mode of life and morphology suggest a primitive organization, like that of Wettsteinina and Pyrenophora (Müller and von Arx 1950). Macroventuria, although superficially similar to Leptosphaerulina, differs in having ascospores that are almost hyaline, matures quickly in pure culture and have ellipsoid ascospores (van der Aa 1971). Ecologically, Leptosphaerulina species are mostly isolated as pathogens from alfalfa and turf grass (Sundheim and Wilcoxson 1965, Abler 2003) whereas Macroventuria species have a saprobic mode of life.

The familial placement based on sequence analyses of these two genera at present is unresolved. Barr (1982) maintained Leptosphaerulina and Macroventuria in the Pseudosphaeriaceae and Eriksson and Hawksworth (1998) accommodated them in the Pleosporaceae, but results show that placement in either of these families is doubtful. This is because (i) phylogenetically they are more closely related to other members of the Leptosphaeriaceae and Phaeosphaeriaceae and (ii) Pseudosphaeriaceae have been treated as a synonym of Pleosporaceae (Shoemaker and Babcock 1987). Although results do not appear to be consistent with any previous classification schemes, there is sufficient evidence to indicate that Macroventuria should not be included in the Venturiaceae (sensu van der Aa 1971). This is because Venturia is phylogenetically distant from most of the 
members of Pleosporales. The traditional placement of Macroventuria in Venturiaceae indicates that morphology of the asci and ascospores and perithecia with well developed setae have been given too much importance.

Position of Wettsteinina (Clade G).—Wettsteinina commonly occurs as pathogens or saprobes on plant leaves and stems (Shoemaker and Babcock 1987) and no molecular studies have addressed phylogenetic relationships of Wettsteinina species at the familial level. Wettsteinina initially was referred to Pseudosphaeriaceae (Wehmeyer 1961), and other authors even considered it as a synonym of Pseudosphaeria (family Pseudosphaeriaceae, order Pseudosphaeriales). Molecular data here show that Wettsteinina is monophyletic but phylogenetically distinct from other members of the Pleosporaceae. Instead it forms a strongly supported sister group relationship with Pleomassaria (Pleosmassariaceae). Luttrell (1955) pointed out that Wettsteinina morpholgically is consistent with Luttrell's Dothidea-type of centrum. Wettsteinina has 1- to 7-transversely septate ascospores and resembles Didymella, Leptosphaeria and Massarina. However Wettsteinina lacks true pseudoparaphyses that are typical of other pleosporaceous members with the exception of Leptosphaerulina (Wehmeyer 1961). Phylogenies generated here indicate that the inclusion of Wettsteinina in the Pleosporaceae is doubtful. With its apparent lack of pseudoparaphyses and phylogenetic distance from other pleosporaceous taxa, we consider that Wettsteinina should be excluded from the Pleosporaceae. Placement within the Pleosmassariaceae merits consideration because Pleomassaria siparia forms a well supported sister group relationship with Wettsteinina species. However to gain further insight into the phylogeny of Wettsteinina, a broader taxon sampling incorporating more taxa from Pleosmassariaceae is necessary.

Polyphyly of Kirschsteiniothelia (Clade D).-Although Kirschsteiniothelia currently is accepted in the Pleosporaceae (Eriksson and Hawksworth 1998, Kirk et al 2001, Eriksson 2005), few phylogenetic studies have included Kirschsteiniothelia species. Massarina ramunculicola formerly was placed in the family Massarinaceae. In contrast Kirschsteiniothelia elaterascus has been referred to the Pleosporaceae. Hawksworth (1985) monographed Kirschsteiniothelia and placed it in Pleosporaceae, but he pointed out the substrate recurrence and the formation of refractive regions in the ascospores possibly reflect distosepta, which are atypical of the Pleosporaceae. Barr (1993a, b) argued that Kirschsteiniothelia belongs to the Pleomassariaceae. Kirschsteiniothelia elaterascus surprisingly does not seem to fit within the Pleomassariaceae or Pleosporaceae. Instead it clusters with Massarina ramunculicola in a single monophyletic clade with high support. A close phylogenetic connection between Kirschsteiniothelia and Massarina was unexpected from a taxonomic viewpoint. Boise (1985) published new combinations of taxa in the Pleomassariaceae and Massarinaceae, suggesting that fungi in these two families have similar characters and might be closely related. Assuming that Barr's treatment is correct (accept Kirschsteinithelia in Pleomassariaceae), then Kirschsteiniothelia also can be closely related to taxa within the Massarinaceae. Kirschsteiniothelia and Massarina possess several characters that unite them. These include 1-celled and fusoid ascospores, cellular pseudoparaphyses and particularly their occurrence on woody litter. Occurrence on this type of woody substratum is atypical in the Pleosporaceae (Hawksworth (1985). Massarina ramunculicola has been shown to have close phylogenetic affinities to the other Massarinaceae (e.g. Massarina arundinariae and M. phragmiticola) (Vijaykrisna pers comm). These relationships however received low statistical support and whether $M$. ramunculicola and Kirschsteiniothelia elaterascus can be assigned to the Massarinaceae is contentious. Kirschsteiniothelia aethiops also was found to be related to Glyphium elatum, whose taxonomic placement within the Dothideomycetes is uncertain (results not shown). We also included Kirschsteiniothelia maritima in other analyses but found that it was not related to the other Kirschsteiniothelia species. It therefore is highly likely that this genus is truly polyphyletic, just as Pleospora.

Systematics of related families. - The family Leptosphaeriaceae was introduced by Barr (1987) and comprises four genera and 119 species (Kirk et al 2001). Classification in the family has been based primarily on the type genus Leptosphaeria, which is morphologically similar to Phaeosphaeria (Kirk et al 2001). The familial position of these two genera within the loculoascomycetes has been debated by several mycologists (e.g. Sivanesan 1984, Barr 1987b, Hawksworth et al 1995, Morales et al 1995). Luttrell (1973), von Arx and Müller (1975) and Sivanesan (1984) placed Leptosphaeria in the Pleosporaceae, while Barr (1987a, b) and Eriksson and Hawksworth (1991) placed it in the Leptosphaeriaceae. Eriksson and Hawksworth (1986) considered that Leptosphaeria should be accommodated better in the Phaeosphaeriaceae. 
The taxonomic delineation of Phaeosphaeria and allied genera such as Leptosphaeria is problematic (Hyde et al 2000). Re-examination and taxonomic reassessment of species previously placed in Leptosphaeria resulted in the disposition of many species into allied genera especially Phaeosphaeria (Hyde et al 2000). Many mycologists realized that there are problems in delimiting Leptosphaeria and Phaeosphaeria because they are similar in gross appearance.

Comparative analyses of the 28S rDNA of Leptosphaeria showed a close phylogenetic relatedness to other members of the Phaeosphaeriaceae, as well as a common evolutionary history pertaining to the Pleosporaceae. Although there is a minor topological incongruence between the parsimony and Bayesian phylogenies, this monophyletic group receives high statistical support and is consistent with existing classification of Phaeosphaeriaceae and Leptosphaeriaceae. Our results are congruent with those reported by Rossman et al (2002) who found that Setomelanomma holmii and Leptosphaeria doliolum are related phylogenetically and in addition both families share close evolutionary relationships to the Pleosporaceae. Despite major differences in opinions in the classification of Leptosphaeria, results show that they are more closely related to the Phaeosphaeriaceae as proposed by Eriksson and Hawksworth (1986). Whether Phaeosphaeriaceae is a synonym of Leptosphaeriaceae needs to be re-evaluated based on a larger taxon sampling and multigene sequence analyses. In other phylogenetic studies, incorporating more taxa from Leptosphaeria, Phaeosphaeria, and Septoria nodorum and Ophiobolus herpotrichus, we found that species from these four genera group into the combined Phaeosphaeriaceae and Leptosphaeriaceae family as a strongly supported monophyletic lineage (Kodsueb et al 2005a). Our results point out that Phaeosphaeriaceae and Leptosphaeriaceae are more closely related to the Pleosporaceae than other families. This has been shown by Rossman et al (2002) and Kodsueb et al (2005a).

Another taxonomic issue addressed in this study is the phylogenetic placement of Bimuria, Karstenula and Trematosphaeria, which all belong to the Melanommataceae (Kirk et al 2001). Of special interest was the sister group relationship of Bimuria and Letendraea. Hawksworth et al (1979) described detailed morphological affinities of Bimuria to Pleospora and Montagnula. It is highly probable that the family Melanommataceae is not strictly monophyletic. The Melanommatales were not monophyletic in an analysis based on a combination of $18 \mathrm{~S}$ and a $28 \mathrm{~S}$ rDNA sequence analyses (Lumbsch and Lindemuth 2001). Kodsueb et al (2005b) have shown that Letendraea does not belong in the Tubeufiaceae and excluded this genus based on morphological and phylogenetic data. Results here also correspond to those of Lumbsch and Lindemuth (2001). Although Preussia and Westerdykella always group together, the position of the strongly supported monophyletic clade varies. MP analyses position these two genera basal to the core of the melanommataceous genera (Bimuria and Karstenula), whereas they cluster with other Melanommataceae and Lophiostomataceae species in the Bayesian analyses. In other sequence datasets it also was found that the addition of anamorphic Sporormiaceae (Berkleasmium micronesicumia and $B$. nigroapicale) resulted in a moderately supported clade characterizing the Sporormiaceae family, which was nested between the Melanommataceae and Pleomassariaceae (Jeewon pers comm).

\section{CONCLUSIONS}

Nine clades of pleosporalean fungi have been identified by our analysis. Although relationships among these clades sometimes are weakly supported and some may vary in detail, some tentative conclusions can be drawn. Several current taxonomic hypotheses are supported by our molecular data, and this makes it possible to propose some taxonomic hypotheses about the relationships among the Pleosporaceae. All taxa within Clade A are monophyletic and are housed within the Pleosporaceae, indicating a single origin of fungi characterized by pseudoparaphyses. However the Pleosporaceae do not appear to be monophyletic in its current circumscription because other members, such as Leptosphaerulina, Macroventuria, Kirschsteiniothelia and Wettsteinina, appear to be more closely related to other families. Pleospora species bearing Stemphylium anamorphs are related to Cochliobolus. Pyrenophora is monophyletic and should be accommodated within Pleosporaceae. Leptosphaerulina and Macroventuria possibly need to be re-assigned to a different family. The phylogeny of Wettsteinina is largely in disagreement with morphology-based schemes and it should be excluded from the Pleosporaceae. Kirschsteiniothelia is probably polyphyletic.

While the taxa presented in this analysis represent a broad range of bitunicate fungi, it is clear that additional taxa, especially from some of the more speciose genera including Kirschsteiniothelia, Pleospora and Wettsteinina, will need to be sampled to resolve the phylogeny in more detail. The presence of the four clades of the Pleosporaceae phylogeny does provide a framework for future taxon selection to strengthen our understanding of Loculoascomycete evolution. Another major observation in this study was the lack of statistical support for any of the major 
nodes within the Pleosporales. Neither 18S (other studies) nor $28 \mathrm{~S}$ sequence analyses could offer significant phylogenetic signal to define proper familial boundaries. Addition of more taxa with broader taxon sampling from all families as well as from other dothideomycetes failed to resolve some of the major clades. Future molecular phylogenetic studies should include different genes as well.

\section{ACKNOWLEDGMENTS}

The University of Hong Kong (RGC 7322/04M) is thanked for financially supporting Dr Rajesh Jeewon and Dr KD Hyde. Fungal Diversity Press of the Centre for Research in Fungal Diversity is thanked for sponsoring Rampai Kodsueb in her doctorate studies and providing her with a student training stipend to visit Hong Kong. BIOTEC Culture Collection (BCC, Thailand), Centraalbureau voor Schimmelcutures (CBS, Netherlands), Hong Kong Culture Collection (HKUCC, Hong Kong) and ICMP (Landcare Research, New Zealand) are thanked for providing fungal cultures. Wellcome W. H. Ho, Helen Leung, A.M.C. Tang, J. Bahl and L. Cai are thanked for their help.

\section{LITERATURE CITED}

Abler SW. 2003. Ecology and Taxonomy of Leptosphaerulina spp. associated with Turfgrasses in the United States (Master's thesis). Blacksburg, Virginia: Virginia Polytechnic Institute and State University. $64 \mathrm{p}$.

Agrios GN. 2005. Plant pathology. 5th ed. Elsevier Academy Press. 922 p.

Barr ME. 1979. A classification of Loculoascomycetes. Mycologia 71:935-957.

- 1982. On the Pleomassariaceae (Pleosporales) in North America. Mycotaxon 15:345-348.

- 1987a. The genus Curreya: an example of taxonomic confusion in the Ascomycetes. Mycologia 73:599609.

- 1987b. Prodomus to class Loculoascomycetes. Amherst, Massachussetts: Hamilton I. Newell, Inc.

- 1993a. Notes on the Pleomassariaceae. Mycotaxon 49:129-142.

- 1993b. Redisposition of some taxa described by J.B. Ellis. Mycotaxon 46:45-76.

Berbee ML. 1996. Loculoascomycete origins and evolution of filamentous ascomycete morphology based on $18 \mathrm{~S}$ rRNA gene sequence data. Mol Biol Evol 13:462-470.

- Pirseyedi M, Hubbard S. 1999. Cochliobolus phylogenetics and the origin of known, highly virulent pathogens, inferred from ITS and glyceraldehyde-3phosphate dehydrogenase gene sequences. Mycologia 91:964-977.

Boise J. 1985. New combinations in the Pleomassariaceae and the Massarinaceae. Mycotaxon 22:477-482.

Borm SV, Billen J, Boomsma JJ. 2002. The diversity of microorganisms associated with Acromyrmex leafcutter ants. BMC Evolutionary Biology 2:9-19.

Cai L, Jeewon R, Hyde KD. 2005. Phylogenetic evaluation and taxonomic revision of Schizothecium based on ribosomal DNA and protein coding genes. Fung Divers 19:1-21.

Ciuffetti LM, Tuori RP. 1999. Advances in the characterization of the Pyrenophora tritici-repentis wheat interaction. Phytopathology 89:444-449.

de Luna LZ, Watson AK, Paulitz TC. 2002. Reaction of rice (Oryza sativa) cultivars to penetration and infection by Curvularia tuberculata and C. oryzae. Plant Dis 86: 470-476.

Dennis RWG. 1978. British Ascomycetes. Germany: J. Cramer. 585 p.

Dong J, Crane W, Crane JL. 1998. Phylogenetic studies of the Leptosphaeriaceae, Pleosporaceae and some other Loculoascomycetes based on nuclear ribosomal NA sequences. Mycol Res 102:151-156.

Ellis JB, Everhart BM. 1892. The North American Pyrenomycetes. Newfield, New Jersey: Published by authors.

Eriksson OE. 1981. The families of bitunicate ascomycetes. Opera Bot 60:1-220.

- 1984. Outline of the Ascomycetes-1984. Syst Ascomycet 3:1-72.

—, Hawksworth DL. 1986. Outline of the Ascomycetes-1986. Syst Ascomycet 5:185-324.

— -1991 . Outline of the Ascomycetes-1991. Syst Ascomycet 9:39-271.

$\longrightarrow$, 1998. Outline of the ascomycetes-1998. Syst Ascomycet 16:83-296.

2005. Outline of Ascomycota-2005. Myconet 11:1-113.

Farr DF, Bills GF, Chamuris GP, Rossman AY. 1989. Fungi on plants and plant products in the United States. The American Phytopathological Society Press.

Felsenstein J. 1985. Confidence limits on phylogenies: an approach using the bootstrap. Evolution 39:783-791.

Hall TA. 1999. BioEdit: a user-friendly biological sequence alignment editor and analysis program for Windows 95/98/NT. Nucl Acid Sympos Ser 41:95-98.

Hawksworth DL. 1985. Kirschsteiniothelia, a new genus for the Microthelia incrustans group (Dothideales). Bot J Linn Soc 91:181-202.

—, Chea CY, Sheridan JE. 1979. Bimuria novaezealandiae gen. et sp. nov., a remarkable ascomycete isolated from a New Zealand barley field. NZ J Bot 17:267-273.

—, Kirk PM, Sutton BC, Pegler DN. 1995. Ainsworth and Bisby's dictionary of the fungi. 8th ed. Wallingford: CAB International.

Huelsenbeck JP, Ronquist F. 2001. MrBayes: Bayesian inference of phylogenetic trees. Bioinformatics 17:754755.

Hyde KD, Taylor JE, Fröhlich J. 2000. Genera of ascomycetes from palms. Fung Divers Res Ser 2:1-247.

Irwin JAG, Davis RD. 1985. Taxonomy of Some Leptosphaerulina spp. on Legumes in Eastern Australia. Aust J Bot 33:233-237.

Jeewon R, Liew ECY, Hyde KD. 2002. Phylogenetic relationships of Pestalotiopsis and allied genera inferred from ribosomal DNA sequences and morphological characters. Mol Phylogenet Evol 25:378-392. 
2003. Molecular systematics of the Amphisphaeriaceae based on cladistic analyses of partial LSU rDNA gene sequences. Mycol Res 107: 1392-1402.

- — - - 2004. Phylogenetic evaluation of species nomenclature of Pestalotiopsis in relation to host association. Fung Divers 17:39-55.

Kirk PM, Cannon PF, David JC, Stalpers JA. 2001. Ainsworth and Bisby's dictionary of the fungi. 9th ed. CABI Publishing.

Kodsueb R, Jeewon R, Ho WH, Hyde KD, McKenzie EHC, Lumyong S. 2005a. Molecular phylogeny of new synnematous hyphomycete taxon from Thailand and its teleomorphic affinities to Massarinaceae (Pleosporales). Bot J Linn Soc (In press).

- - —, Vijaykryshna D, Lumyong P, McKenzie EHC, Lumyong S, Hyde KD. 2005b. A revision of Tubeufiaceae based on morphological and molecular data (LSU rDNA). Fung Divers 21:104-129.

Krupinsky JM, Berdahl JD, Schoch CL, Rossman AY. 2004. Leaf spot on switch grass (Panicum virgatum), symptoms of a new disease caused by Bipolaris oryzae. Can J Plant Path 26:371-378.

Liew ECY, Aptroot A, Hyde KD. 2000. Phylogenetic significance of the pseudoparaphyses in loculoascomycete taxonomy. Mol Phylogenet Evol 16:392-402.

Lindau G. 1897. Pyrenomycetineae. In Engler and Prantl. Die natürlichen Pflanzenfamilien. I. 1:321-491.

Liu YJ, Whelen S, Hall BD. 1999. Phylogenetic relationships among ascomycetes: evidence from an RNA Polymerase II Subunit. Mol Biol Evol 16:1799-1808.

Lumbsch HT. 2000. Phylogeny of filamentous ascomycetes. Naturwissenschaften 87:335-342.

— L Lindemuth R. 2001. Major lineages of Dothideomycetes (Ascomycota) inferred from SSU and LSU rDNA sequences. Mycol Res 105:1-120.

— Schmitt I, Messuti MI. 2001. Utility of nuclear SSU and LSU rDNA datasets to discover the ordinal placement of the Coccotremataceae (Ascomycota). Org Divers Evol 1:99-112.

Luttrell ES. 1955. The ascostromatic ascomycetes. Mycologia 47:511-532.

- 1973. Loculoascomycetes. In: Ainsworth GC, Sparrow FK, Sussman AS, eds. The fungi: an advanced treatise. New York: Academic Press. p 135-219.

Lutzoni F, Wagner P, Reeb V, Zoller S. 2000. Integrating ambiguously aligned regions of DNA sequences in phylogenetic analyses without violating positional homology. Syst Biol 49:628-651.

Morales VM, Jasalavich CA, Pelcher LE, Petrie GA, Taylor JL. 1995. Phylogenetic relationship among several Leptosphaeria species based on their ribosomal DNA sequences. Mycol Res 99:593-603.

Müller E, von Arx JA. 1950. Einige Aspekten zur Systematik pseudosphärialer Ascomyceten. In Ber Schweiz Bot Ges 60:329-397.

Nitschke TRJ. 1869. Pleosporaceae. Verh. Naturhist. Ver Preuss Rheinl 26:74.

Nylander JAA. 2004. MrModeltest 2.2. Program distributed by the author Evolutionary Biology Centre, Uppsala University.

Paul AR, Parbery DG. 1968. Pyrenophora dictyoides sp. nov., the perfect state of Helminthosporium dictyoides. Trans Br Mycol Soc 51:707-710.

Rambaut A. 1996. Se-Al: sequence alignment editor. Available at http://evolve.zoo.ox.ac.uk/. Oxford, UK: Department of Zoology, University of Oxford.

Reynolds DR. 1991. A phylogeny of fissitunicate ascostromatic fungi. Mycotaxon 42:99-123.

Rossman AY, Farr DF, Castlebury LA, Shoemaker R, Mengistu A. 2002. Setomelanomma holmii (Pleosporales, Phaeosphaeriaceae) on living spruce twigs in Europe and North America. Can J Bot/Rev Can Bot 80: 1209-1215.

Shoemaker RA, Babcock CE. 1987. Wettsteinina. Can J Bot 65:373-405.

Silva-Hanlin DMW, Hanlin RT. 1999. Small subunit ribosoal RNA gene phylogeny of several loculoascomycetes and its taxonomic implications. Mycol Res 103:153-160.

Sivanesan A. 1984. The bitunicate Ascomycetes and their anamorphs. Vaduz, Germany: Strauss and Cramer.

Sundheim L, Wilcoxson RD. 1965. Leptosphaerulina briosiana on alfalfa: infection and disease development, host-parasite relationships, ascospore germination and dissemination. Phytopathology 55:546-553.

Swofford DL. 2002. PAUP*: phylogenetis analysis using parsimony (*and other methods), version $4.0 \mathrm{~b} 10$. Sunderland, Massachusetts: Sinauer Associates.

Theissen F, Sydow H. 1917. Synoptische Tafeln. Ann Mycol 15:389-396.

Thompson JD, Gibson TJ, Plewniak F, Jeanmougin F, Higgins DG. 1997. The Clustal X Windows interface: flexible strategies for multiple sequence alignment aided by quality analysis tools. Nucl Acid Res 25: 4876-4882.

van der Aa HA. 1971. Macroventuria, a new genus of the Venturiaceae. Persoonia 6:359-363.

Vilgalys R, Hester M. 1990. Rapid genetic identification and mapping of enzymatically amplified ribosomal DNA from several Cryptococcus species. J Bacteriol 172: 4238-4246.

von Arx JA, Müller E. 1975. A re-evaluation of the bitunicate ascomycetes with keys to families and genera. Stud Mycol 9:1-159.

Wehmeyer LE. 1961. A world monograph of the genus Pleospora and its segregates. Ann Arbor: University of Michigan Press. 451 p.

. 1975. The pyrenomycetous fungi. Mycologia Memoir No. 6. The New York Botanical Garden. Germany: J. Cramer Publishing. $250 \mathrm{p}$.

Winter G. 1887. Ascomyceten. In Rabenhorst's Dié Pilze Deutschlands, Oesterreichs und der Schweiz. Bd. I, Abt. II, 1-928.

Wu M, Hanlin RT. 1992. Ascomal development in Leptosphaerulina crassiasca. Mycologia 84:241-252.

Zhang G, Berbee ML. 2001. Pyrenophora phylogenetics inferred from ITS and glyceraldehydes-3-phosphate dehydrogenase gene sequences. Mycologia 93:10481063. 